\title{
Improvement of Microbiological Quality of Hen Egg Powder Using Gamma Irradiation
}

\author{
M. AL-BACHIR ${ }^{a^{*}}$ \\ ${ }^{\text {a }}$ RadiationTechnologyDep. AtomicEnergyCommission of Syria, P.O.Box: 6091, Damascus, Syria \\ ${ }^{*}$ Corresponding author \\ ascientific@aec.org.sy \\ TEL: 009-63-11-2132580
}

Received: 2 Dezembro 2018; Published online: 18 January 2020

\begin{abstract}
Eggs and their products such as desserts, confectioneries, bakery mixes, mayonnaise and many convenience foods have been implicated in food-borne disease outbreaks due to microorganism contamination. The effect of gamma irradiation on the presence of microorganisms in egg powder was investigated. Egg powder samples were exposed to several doses of irradiation: 0, 5, 10 and $15 \mathrm{kGy}$ and stored for up to 12 months at ambient temperature $\left(25^{\circ} \mathrm{C}\right)$. Results indicated that the total viable count (TVC) (5.56 $\left.\log _{10} \mathrm{cfu} \mathrm{g}^{-1}\right)$, total coliform counts (TCC) $\left(6.46 \log _{10} \mathrm{cfu} \mathrm{g}^{-1}\right)$ and mold and yeast counts (MYC) (9.12 $\log _{10} \mathrm{cfu}$ g) in un-irradiated (control) samples of egg powder were higher than the maximum limits $\left(4.88,2.00\right.$ and $1.70 \log _{10} \mathrm{cfu} \mathrm{g}^{-1}$, respectively). Application of the higher doses (10 and $15 \mathrm{kGy}$ ) decreased the TVC, TCC and MYC of the egg powder samples to less than $1 \log _{10} \mathrm{cfu} \mathrm{g}^{-1}$ and the counts remained almost constant during storage for 12 months. $\mathrm{D}_{10}$ values for Escherichia coli and Salmonella typhimurium were 0.714 and $0.278 \mathrm{kGy}$, respectively. Gamma irradiation treatment could be chosen on the basis of preliminary microbiological tests including TVC, TCC and MYC and help improve the hygienic quality by killing and reducing the microorganisms that might be present inside of egg powder to meet national and international standards.
\end{abstract}

Keywords: Egg powder; Gamma irradiation; Total viable count; Total coliform count; Mold and yeast count

\section{Introduction}

Egg is one of the most versatile and near perfect foods in nature, and its essential components form a balanced diet (Akpinar-Bayizit, Ozcan, Yilmaz-Ersan, \& Gurbuz, 2010; Ndife, Udobi, \& Amaechi, 2010).

Microbial contamination of eggs is a wellestablished phenomenon and has an important economic implication to the poultry industry (Farag et al., 2012; Wong \& Kitts, 2002). Eggs become infected through a process of either transmission, or with moist faces contaminated with Salmonella. Following traversing of the eggshell, the associated membrane of the egg becomes permeable to Salmonella and other pathogens (Dadashi, Kiani, Rahimi, \& Mousavi, 2017; Holt et al., 2011; Jaffer \& Nazal, 2013; Nemeth et al., 2011).

Safety of the internal compartments of eggs, in the new alternative poultry production systems, could be microbiologically altered (Holt et al., 2011; Jaffer \& Nazal, 2013). Consequently, researchers emphasized the need to rapidly remove any microbial contamination in order to reduce the risk of microbial penetration into the egg contents (Al-Bachir \& Zeinou, 2006; Farag et al., 2012; Tan, Kanyarat, \& Easa, 2012). Recently, 
the use of shelled egg in food production, as a raw material, has been reduced with the technological developments around the world food industry, and egg products such as frozen egg, and pasteurized liquid egg products have gained popularity (Koc et al., 2011; Ndife et al., 2010). Industrially, dehydrated eggs have many advantages over fresh ones, like inhibition of microorganism development, easier handing and a significant extension in their shelf life (de Jesus et al., 2013; Kumaravel et al., 2011). Drying is a technique used for preserving liquid food, by converting it to a powder form. The whole egg powder obtained by the processes employed, including all methods of drying, was subjected to different studies (Asghar \& Abbas, 2012; Schuck et al., 2009).

With growing concerns about food safety, the use of irradiation has been well accepted as one of the best methods for the production of safe meat and poultry (Al-Bachir, 2010; Al-Bachir \& Zeinou, 2006). Food irradiation is a non-thermal method, or used as an additional food safety tool, that serves as a compliment to other food safety technologies (Kim et al., 2016). Irradiation of egg and egg products has been used experimentally, as an alternative to heat pasteurization to eliminate Salmonella, which is a naturally occurring pathogen in eggs that causes a serious infection (Al-Bachir \& Zeinou, 2006; Farag et al., 2012; Kim et al., 2016). Most research on microbial inactivation has tried to determine the proper irradiation dosage to pasteurize egg products. Since 2000, the food and drug administration (FDA), approved the use of up to $3 \mathrm{kGy}$ ionizing radiation dose to reduce the level of Salmonella in eggs (Shahin, Swailam, \& Abou Zeid, 2006).

The quality evaluation of food products is critical to improve the processing conditions for getting better quality products. Therefore, the aim of the present study was to use gamma irradiation to enhance safety of egg powders, and to analyze the microbial load of an egg powder after irradiation.

\section{Materials and Methods}

Fresh good quality eggs were obtained from Sidnaia poultry farms, in Damascus Syria. The eggs were candled to confirm their freshness and were cleaned by dusting, washing to remove dirt and other undesirable materials, to avoid any contamination and allowed to dry. They were carefully de-shelled and whole egg liquid obtained in a graduated cylinder. Whole egg liquid was mixed in a blender (WARING commercial blender model 32BL80 made in U.S.A.) for 1-2 min, liquid egg was spread thinly $(0.5-1.0 \mathrm{~mm}$ thickness) on a tray, and oven dried at $60{ }^{\circ} \mathrm{C}$ for 48 hours in a laboratory oven (MEMMERT model 600) to constant mass and allowed to cool. Egg flakes were scooped, milled and sieved with $60 \mathrm{~mm}$ mash before being weighed. The egg powders were packed into different plastic films for further investigation.

\subsection{Irradiation treatment}

Egg powder were irradiated with doses of 0,5 , 10 and $15 \mathrm{kGy}$, at room temperature, using a gamma source ${ }^{60} \mathrm{CO}$ (ROBO, Russia) with a dose rate of $7.775 \mathrm{kGy} \mathrm{h}^{-1}$. The absorbed dose was monitored by alcoholic chlorobenzene dosimeter (Al-Bachir, 2010). The irradiated and control samples of egg powders were stored for 12 months at ambient temperature $\left(18-25^{\circ} \mathrm{C}\right)$ under relative humidity $(\mathrm{RH})$ of $50-70 \%$.

\subsection{Microbiological evaluation}

Standard plate count method was employed to enumerate the microbial load in terms of colony forming units $\left(\mathrm{cfu} \mathrm{g}^{-1}\right)$ in control and irradiated samples after 0, 6 and12 months of storage. Three replicates from each treatment were used, and $10 \mathrm{~g}$ of powdered egg samples was homogenized with serial dilutions were prepared according to standard methods (AOAC, 2010). Total viable count (TVC) was determined on diagnostic plate count agar (PCA) (Oxoid, CM 325 , UK). Samples were incubated at $30^{\circ} \mathrm{C}$ for $48 \mathrm{hr}$. Total coliform count (TCC) was determined on a Violet Red Bile Agar (VRBA) (Oxoid, CM 485, UK) at $37^{\circ} \mathrm{C}$ for $48 \mathrm{~h}$. Total mold and yeast (TMY) was done on Dichloran RoseBengal Chloramphenicol Agar (DRBC) (Merck, 1.00466, Germany) after incubation at $25^{\circ} \mathrm{C}$ for 5 days. The colony count was reported as colony

\begin{tabular}{l|l|l|l} 
IJFS & January 2020 & Volume 9 & pages SI75-SI83
\end{tabular} 
forming units per gram of egg powder samples $\left(\mathrm{cfu} \mathrm{g}^{-1}\right)$. Microbial counts were transformed to $\log _{10} \mathrm{cfu} \mathrm{g}^{-1}$. To determine the survival curves before irradiation, eggs were artificially inoculated by thoroughly mixing them with a suspension of Salmonella. The suspension was prepared by mixing a culture colony of Salmonella with pure peptone water media. The Salmonella count in the prepared suspension was $10^{7}$ per $\mathrm{ml}$. Before inoculation, eggs were sterilized using gamma irradiation $(25 \mathrm{kGy})$. The ratio of inoculation was $1 \mathrm{ml}$ suspension to $9 \mathrm{ml}$ eggs. The survival curve was estimated from irradiation doses of $0.5,1.0,1.5,2.0,2.5$ and $3.0 \mathrm{kGy}$. The survival level of Salmonella was determined by plate counting on Xylose Lysine Desoxycholate Agar (XLD) after 2 days of incubation at $37^{\circ} \mathrm{C}$. Similarly, the survival level of $E$. coli was determined by plate counting on Eosin Methylene Blue Agar (EMBA) (Oxoid, CM 69, UK), after 2 days of incubation at $37^{\circ} \mathrm{C} . \mathrm{D}_{10}$ value was calculated using the Cricketgraph (Cricket Software, Maluern, PA, USA) computer package.

\subsection{Water activity determination}

Water activity was determined using reference solutions (Al-Bachir, 2010).To determine the range capacity and calibration sensitivity of the measurement, the water activity of twelve saturated salt solutions was measured at $20{ }^{\circ} \mathrm{C}$. Saturation equilibrium of solutions was checked after storage for $2 \mathrm{hr}$ at $25{ }^{\circ} \mathrm{C}$ prior to measurement.

\subsection{Statistical analysis}

Four treatment doses $(0,5,10$ and $15 \mathrm{kGy})$, and three storage periods ( 0,6 and 12 months) were distributed in a completely randomized design with three replicates for each treatment. Data were subjected to the analysis of variance test (ANOVA) using the SUPERANOVA computer package (Abacus Concepts Inc, Berkeley, CA, USA; 1998). The $\mathrm{p}$ value of less than 0.05 was considered statistically significant.

\section{Results and Discussions}

\subsection{Microbiological qualities of egg powder}

The extent of contamination by microorganisms in egg powder products was determined. As shown in (Table 1), the mean total viable count (TVC), total coliform counts (TCC) and mold and yeast count (MYC) for the control sample of egg powder were 5.56, 2.62 and $2.33 \log _{10} \mathrm{cfu}$ $\mathrm{g}^{-1}$, respectively. Coliforms are defined as rod shaped gram-negative non-spore forming bacteria. They are a commonly used indicator of sanitary quality of foods. During storage at room temperature, the microorganisms in egg powder products increased gradually reaching, at the end of the storage period (12 months), 9.12, 3.04 and $4.03 \log _{10} \mathrm{cfu} \mathrm{g}^{-1}$ for TVC, TCC and MYC respectively, indicating a high contamination percentage of these products. Microbiological population of used egg powder was found to be comparatively high, which was not in accordance with the national and international standards for egg powder that include less than $7.5 \times 10^{4}$ cfu $\mathrm{g}^{-1}$ in TVC, less than $100 \mathrm{cfu} \mathrm{g}^{-1}$ in TCC, less than $50 \mathrm{cfu}^{-1}$ in MYC (CODEX, 2007; SASMO, 2007). Although MYC contaminated egg powder products were relatively lower than TVC, their counts were also above the safety limits (Table 1). Our previous studies also indicated that the microbial contamination level was above the international and national limits in commercially available dried powder food products found in local markets (Al-Bachir, 2007; Al-Bachir \& Al-Adawi, 2015; Al-Bachir, 2017). TVC is indicative of the populations of contaminated microorganisms, and act as an index of hygienic quality. On farms where eggs are produced, the sources of bacterial contaminants have been shown to be surrounding environment, as well as the chickens (Shahin et al., 2006). Microorganisms on the surface of the shell are able to pass through the pores of the shell to contaminate the interior of the egg (Foley \& Lynne, 2008; Gantois et al., 2009; Jaffer \& Nazal, 2013).

The results of the current research indicated that, Salmonella spp and E. coli were detected in fresh egg (Table 2). In the case of Salmonella 
spp and E. coli in samples of fresh egg did not meet local and international standards of zero tolerance for food for human nutrition including eggs, absent in Salmonella spp, and negative in Staphylococcus aureus (CODEX, 2007; SASMO, 2007). The presence of Salmonella and E. coli in fresh egg samples, as well as in egg powder, may be the result of contamination from the environment and personal or from the raw materials used for preparation. E. coli in $10 \mathrm{~g}$ egg powder was detected, while Salmonella spp. were absent in $25 \mathrm{~g}$ egg powder, as demanded in our legislation (Table 2).

Much attention has been given to the role chicken eggs play in the transmission of bacteria, such as Salmonella to human populations (Shahin et al., 2006). The TCC and E. coli detected in egg powder samples was an indication of contamination by fresh fecal matter. High TCC are usually associated with significant levels of enteric pathogens (Adu-Gyamfi, Torgby-Tetteh, \& Appiah, 2012). This, according to FDA (2011), can cause cholera, bloody diarrhea, and kidney failure in people with weak immune systems. Shell eggs and egg-containing products are the most significant sources of Salmonella (Min, Nam, Jo, \& Ahn, 2012). Salmonella Enteritidis and Salmonella Typhimurium are the most commonly isolated serotypes in human cases of Salmonellosis, and contaminated egg is a very important source of infection with $S$. Enteritidis for humans (Rakonjac et al., 2014).

\subsection{Effect of gamma irradiation on microbiological qualities of egg powder}

Application of 10 and $15 \mathrm{kGy}$ doses was enough to decrease the TVC, TCC and MYC in the egg powder to the safety level (to less than $1 \log _{10} \mathrm{cfu}$ $\mathrm{g}^{-1}$ ), and the counts remained almost constant during storage for 12 months as clearly observed in Table 1. The TVC was found to decrease with a 5 kGy dosage, while TCC and MYC values of irradiated egg powder samples was found to be absent in irradiated samples with the same dose (at $5 \mathrm{kGy}$ ). In the present study, the mode of gamma irradiation processing of the egg powder products with the doses of 10 and $15 \mathrm{kGy}$, were chosen on the basis of preliminary microbiological tests. Since both doses $(10 \mathrm{kGy}$ and 15 kGy) completely eliminated microorganisms from the egg powder products. This observation underscores the need for Good Manufacturing Practices (GMP) in production protocols to ensure products have low contamination, and acceptable hygienic quality, and would be in line with the national and international criteria for decontamination of dry foods (SASMO, 2010). This is to be expected, since irradiation is one of the few processes that eliminates disease-causing microorganisms from foods and guarantees high hygienic quality (Adu-Gyamfi et al., 2012). The results corroborate the findings of Aquino, Lui, and Correa (2017), who observed that for the complete elimination of microorganisms in egg powder, it was necessary to use doses around 10 kGy.

Egg disinfection has two purposes. One is to reduce the overall abundance of TVC and MYC that may affect egg respiration and survival. The other is to reduce or eliminate pathogens that may affect egg and fry survival, and compromise the health certification of a hatchery (Barnes, Bergmann, Stephenson, Gabel, \& Cordes, 2005). Results of this study indicated that the current practices of gamma irradiation treatment achieve the first and second objectives. This is important for situations in which hatcheries receive eggs from wild sources, or from other hatcheries and processes.

Our results are consistent with literature data, since similar results were obtained in a study performed on dried products similar to egg powder. A previous study showed that gamma irradiation at a dose range of $10-20 \mathrm{kGy}$ was sufficient to eliminate or reduce to an acceptable level, the microbiological contamination of licorice root powders (Al-Bachir \& Al-Adawi, 2015), chamomile powder (Al-Bachir, 2017) and aniseed (Al-Bachir, 2007).

Farag et al. (2012) and Adhitia, Octaviani, Rissyelly, Basah, and Mun'im (2017) mentioned that, ionizing irradiation inactivates microorganisms directly by lethal damage of microbial DNA, therefore obstructing bacterial division, and indirectly by free radicals generated during water radiolysis that disintegrate microbial cell membranes.

\begin{tabular}{l|l|l|l} 
IJFS & January 2020 & Volume 9 & pages SI75-SI83
\end{tabular} 
Microbiological quality of egg powder $\mid$ SI79

Table 1: Effect of gamma irradiation and storage period on total viable count (TVC), total coliform count (TCC) and total mold and yeast count (TMY) of egg powder $\left(\log _{10} \mathrm{cfu} \mathrm{g}^{-1}\right)$.

\begin{tabular}{|c|c|c|c|c|c|}
\hline Treatments & Control & $5 \mathrm{kGy}$ & $10 \mathrm{kGy}$ & $15 \mathrm{kGy}$ & P-level \\
\hline \multicolumn{2}{|c|}{ Storage period (Months) } & \multicolumn{4}{|c|}{ Total viable count (TVC) $\left(\log _{10} \mathrm{cfu} \mathrm{g}^{-1}\right)$} \\
\hline 0 & $0.05 \pm 5.56^{a C}$ & $0.05 \pm 3.40^{b C}$ & $>1$ & $>1$ & 0.0001 \\
\hline 6 & $0.18 \pm 6.46^{a B}$ & $0.08 \pm 3.83^{b B}$ & $>1$ & $>1$ & 0.0001 \\
\hline 12 & $0.29 \pm 9.12^{a A}$ & $0.06 \pm 4.14^{b A}$ & $>1$ & $>1$ & 0.0001 \\
\hline \multirow[t]{2}{*}{ P-level } & 0.0001 & \multicolumn{4}{|l|}{0.0001} \\
\hline & & \multicolumn{4}{|c|}{ Total coliform count (TCC) $\left(\log _{10} \mathrm{cfu} \mathrm{g}^{-1}\right)$} \\
\hline 0 & $0.08 \pm 2.62^{a C}$ & $>1$ & $>1$ & $>1$ & 0.0001 \\
\hline 6 & $0.04 \pm 2.84^{a B}$ & $>1$ & $>1$ & $>1$ & 0.0001 \\
\hline 12 & $0.1 \pm 3.040^{b A}$ & $>1$ & $>1$ & $>1$ & 0.0001 \\
\hline \multirow[t]{2}{*}{ P-level } & 0.0001 & & & & \\
\hline & & \multicolumn{4}{|c|}{ Total mold and yeast count (TMY) $\left(\log _{10} \mathrm{cfu} \mathrm{g}^{-1}\right)$} \\
\hline 0 & $0.03 \pm 2.33^{a C}$ & $>1$ & $>1$ & $>1$ & 0.0001 \\
\hline 6 & $0.21 \pm 3.49^{a A}$ & $>1$ & $>1$ & $>1$ & 0.0001 \\
\hline 12 & $0.19 \pm 4.03^{a B}$ & $>1$ & $>1$ & $>1$ & 0.0001 \\
\hline P-level & 0.0015 & & & & \\
\hline $\begin{array}{l}a b c \text { Mean val } \\
\text { different. } \\
A B C \text { Mean v } \\
\text { different. } \\
\text { NS: not sign } \\
\text { * Significant } \\
* * \text { Significan }\end{array}$ & $\begin{array}{l}\text { des in the sam } \\
\text { lues in the sa } \\
\text { ficant. } \\
\text { at } \mathrm{p}<0.05 \text {. } \\
\text { at } \mathrm{p}<0.01 \text {. }\end{array}$ & $\begin{array}{l}\text { column not sh } \\
\text { e row not shat }\end{array}$ & $\begin{array}{l}\text { aring a } \mathrm{s} \\
\text { ing a sup }\end{array}$ & $\begin{array}{l}\text { perscript } \\
\text { rscript at }\end{array}$ & $\begin{array}{l}\text { are significantly } \\
\text { e significantly }\end{array}$ \\
\hline
\end{tabular}

Table 2: Effect of gamma irradiation on Escherichia coli and Salmonella typhimurium contaminating egg powder

\begin{tabular}{llllll}
\hline \multirow{2}{*}{ Treatments } & \multirow{2}{*}{ Fresh egg } & Egg powder & $\begin{array}{l}\text { Egg powder } \\
5 \mathrm{kGy}\end{array}$ & $\begin{array}{l}\text { Egg powder } \\
10 \mathrm{kGy}\end{array}$ & $\begin{array}{l}\text { Egg powder } \\
15 \mathrm{kGy}\end{array}$ \\
\hline Escherichia coli & $\mathrm{D}$ & $\mathrm{D}$ & $\mathrm{ND}$ & $\mathrm{ND}$ & $\mathrm{ND}$ \\
Salmonella typhimurium & $\mathrm{D}$ & $\mathrm{ND}$ & $\mathrm{ND}$ & $\mathrm{ND}$ & $\mathrm{ND}$ \\
\hline
\end{tabular}

D: Detected ND: not detected 
SI80 $\mid$ Al-Bachir

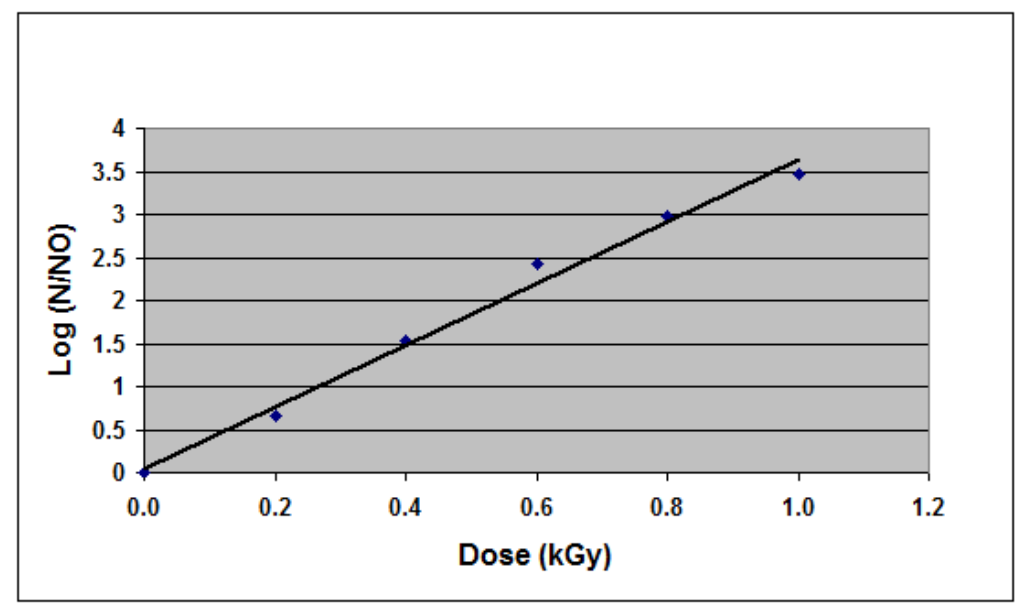

Figure 1: Behavior of $E$. coli inoculated egg powder samples subjected to gamma irradiation at $0,0.2$, $0.6,0.8,1.0$ and $1.2 \mathrm{kGy}$ (three replicates). $(\mathrm{y}=3.5929 \mathrm{x}+0.0488)\left(\mathrm{R}^{2}=0.9885\right)$.

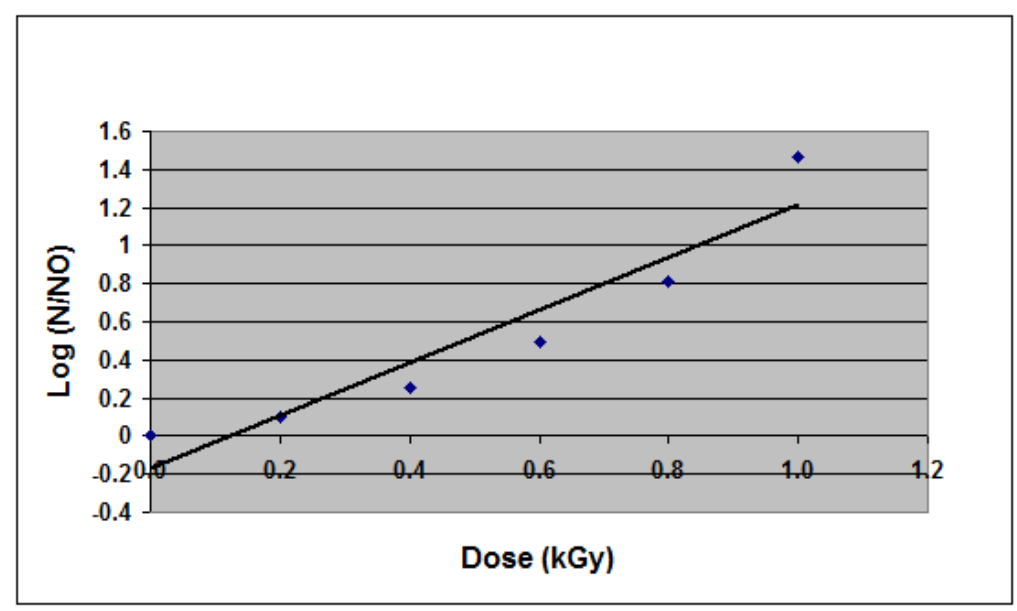

Figure 2: Behavior of Salmonella spp inoculated egg powder samples subjected to gamma irradiation at $0,0.2,0.6,0.8,1.0$ and $1.2 \mathrm{kGy}$ (three replicates). $(\mathrm{y}=1.3901 \mathrm{x}-0.1738),\left(\mathrm{R}^{2}=0.8973\right)$. 
The values of decimal reduction dose ( $\mathrm{D}_{10}$ value) for Salmonella of the powdered egg is $0.714 \mathrm{kGy}$ (Figure 1), while the $\mathrm{D}_{10}$ value for $E$. coli. of the powdered egg is $0.278 \mathrm{kGy}$ (Figure 2). Results of the present study are in agreement with those obtained by Froehlich, Gombossy de Melo Franco, Destro, and Landgraf (2015) which indicated that irradiated powdered egg inoculated with Salmonella had $\mathrm{D}_{10}$ values which varied from 0.76 to $0.86 \mathrm{kGy}$. Kim et al. (2016) have reported that the $\mathrm{D}_{10}$ value of electron beam irradiated egg powder was $0.26 \mathrm{kGy}$ for both Salmonella typhimurium and E. coli. $\mathrm{D}_{10}$ values of bacteria in food are affected by some factors including water activity. The relatively high $\mathrm{D}_{10}$ values for both Salmonella and E. coli in the present study may be due to the lower water content of the egg powder, since the water activity for used egg powder is 0.50 or $0.56 \%$ at $24{ }^{\circ} \mathrm{C}$. Such a low water activity provides longer storage life, because the absolute limit for microbial growth is higher than 0.6 (Kumar, Gautam, Powar, \& Sharma, 2010). Although, Salmonella spp cannot actively multiply in water below 0.92 , they can survive for long periods in eggs (Froehlich et al., 2015). In preserving foods by drying, one seeks to lower the moisture content to a point where the activities of food spoilage and food-poisoning microorganisms are inhibited. Dried or Low Moisture Foods (LMF) are those that generally do not contain more than $25 \%$ moisture, and have a water activity (aw) between 0.00 and 0.60. Intermediate Moisture Foods (IMF) have $\mathrm{a}_{w}$ values of 0.60 to 0.85 (with moisture contents of 15 to $50 \%$ ). They can be eaten without rehydration, but their shelf-life lasts for a relatively long period of time without refrigeration and they are considered microbiologically safe (Syamaladevi et al., 2016).

\section{Conclusion}

The results of this study demonstrated that the microbiological quality of an egg powder such as total viable counts (TVC), total coliform counts (TC) and mold and yeast counts (MYC) are significantly affected by gamma irradiation. An irradiation dose level of $10 \mathrm{kGy}$ is a promising treatment for decontamination of dried hen egg powder products. The treatment is sufficient to eliminate or reduce TVC, TC and MYC and to maintain products of hygienic quality within safe levels as recommended by national and international food and health organizations either directly after irradiation or during storage.

\section{Acknowledgements}

The author wishes to express deep appreciation to the Director General of the Atomic Energy Commission of Syria (AECS) and the staff of the division of food irradiation.

\section{References}

Adhitia, A. M., Octaviani, A. N., Rissyelly, Basah, K., \& Mun'im, A. (2017). Effect of gamma irradiation on angiotensin converting enzyme inhibition, antioxidant activity, total phenolic compound and total flavonoid of peperomia pellucida herbs extract. Pharmacognosy Journal, 9, 244-248. doi:10.5530/pj.2017.2.41

Adu-Gyamfi, A., Torgby-Tetteh, W., \& Appiah, V. (2012). Microbiological quality of chicken sold in accra and determination of d 10 -value of e. coli. Food and Nutrition Sciences, 335094, 693-698. doi:10.4236/ fns.2012.35094

Akpinar-Bayizit, A., Ozcan, T., Yilmaz-Ersan, L., \& Gurbuz, O. (2010). Impact of processing methods on nutritive value and fatty acid profile of hen eggs. Pakistan Veterinary Journal, 30(4), 219-222.

AOAC. (2010). Official Methods of Analysis, 15 th edn. Association of Official Analytical Chemists, Washington, D.C.

Aquino, S., Lui, C. C., \& Correa, B. (2017). Gamma radiation treatment applied to microbial decontamination of products derived from eggs collected from the retail market in são paulo. Arquivo Brasileiro de Medicina Veterinária e Zootecnia, 69, 1683-1692. doi:10.1590/1678-4162-9241

Asghar, A., \& Abbas, M. (2012). Dried egg powder utilization, a new frontier in bakery products. Agriculture and Biology Journal 
of North America, 3, 493-505. doi:10.5251/ abjna.2012.3.12.493.505

Al-Bachir, M. (2007). Effect of gamma irradiation on microbial load and sensory characteristics of aniseed (pimpinella anisum). Bioresource Technology, 98(10), 1871-1876.

Al-Bachir, M. (2010). Effect of gamma irradiation on microbial load, chemical and sensory properties of sheesh tawoq; prepared chilled meal. Acta Alimentaria, 39(1), 8189. doi:10.1556/AAlim.39.2010.1.8

Al-Bachir, M., \& Al-Adawi, M. (2015). Comparative effect of irradiation and heating on the microbiological properties of licorice (Glycyrrhiza glabra L.) root powders. International Journal of Radiation Biology, 91(1), 112-116. doi:10 . 3109 / 09553002. 2014.944284

Al-Bachir, M. (2017). Control of natural microorganisms in chamomile (chamomilla Recutita $L$.) by gamma ray and electron beam irradiation. Acta Scientiarum Polonorumtechnologia Alimentaria, 16(1), 17-23. doi:10.17306/J.AFS.2017.0410

Al-Bachir, M., \& Zeinou, R. (2006). Effect of gamma irradiation on some characteristics of shell eggs and mayonnaise prepared from irradiated eggs. Journal of Food Safety, 26(4), 348-360. doi:10.1111/j.1745-4565. 2006.00054.x

Barnes, M. E., Bergmann, D., Stephenson, H., Gabel, M., \& Cordes, R. J. (2005). Bacterial numbers from landlocked fall chinook salmon eyed eggs subjected to various formalin treatments as determined by scanning electron microscopy and bacteriological culture methods. North American Journal of Aquaculture, 67(1), 23-33. doi:10. 1577/FA04-019.1

CODEX. (2007). Alimmentarius commission. Joint FAO/WHO food standards programme "Code of hygienic practice for eggs and egg products (CAC/RCP 15-1976) was adopted 1976. Amendments 1978. 1985.

Dadashi, S., Kiani, H., Rahimi, H., \& Mousavi, S. M. (2017). Effect of freezing-thawing and stabilizers on the phase behavior of egg micro-particles and quality attributes of liquid egg. Journal of Agricultural Science and Technology, 19(4), 821-834.

de Jesus, M. N., Zanqui, A. B., Valderrama, P., Tanamati, A., Maruyama, S. A., de Souza, N. E., \& Matsushita, M. (2013). Sensory and physico-chemical characteristics of desserts prepared with egg products processed by freeze and spray drying. Food Science and Technology, 33(3), 549-554. doi:10.1590/S0101-20612013005000083

Farag, M. D. H., Eissa, F., A., F., Mohamed, Nasef, S., \& Azeem A. M., A. (2012). Sanitation of fresh chicken eggs by ionizing radiation and its effect on their physicochemical and functional properties. Isotope and Radiation Research, 44, 379-400.

FDA. (2011). Food and Drug Administration. Retail meat report national antimicrobial resistance monitoring system. Rockville: Food and Drug Administration.

Foley, S., \& Lynne, A. (2008). Food-associated salmonella challenges: Pathogenicity and antimicrobial resistances. Journal of animal science, 86, E173-87. doi:10.2527/jas. 2007-0447

Froehlich, A., Gombossy de Melo Franco, B. D., Destro, M. T., \& Landgraf, M. (2015). Sensory aspects and reduction of salmonella in irradiated egg powder. Ciencia e Agrotecnologia, 39(5), 506-513. doi:10 . $1590 /$ S1413-70542015000500009

Gantois, I., Ducatelle, R., Pasmans, F., Haesebrouck, F., Gast, R., Humphrey, T. J., \& Van Immerseel, F. (2009). Mechanisms of egg contamination by salmonella enteritidis. Fems Microbiology Reviews, 33(4), 718-738. doi:10.1111/j.1574-6976 . 2008. 00161.x

Holt, P. S., Davies, R. H., Dewulf, J., Gast, R. K., Huwe, J. K., Jones, D. R., ... Willian, K. R. (2011). The impact of different housing systems on egg safety and quality. Poultry Science, 90(1), 251-262. doi:10.3382/ ps.2010-00794

Jaffer, M. R., \& Nazal, K. K. (2013). Contamination of local laying hen's egg shell with salmonella serotypes. The Iraqi Journal of Veterinary Medicine, 37(1), 13-16. Retrieved from https://www.iasj.net/iasj? func $=$ article $\% 5$ C\&aId $=78639$ 
Kim, H.-J., Yong, H. I., Jayasena, D. D., Lee, H. J., Lee, H., \& Jo, C. (2016). Microbial safety and physicochemical characteristics of electron beam irradiated whole egg powder. Food Science and Biotechnology, 25(2), 637-642. doi:10.1007/s10068-0160089-4

Koc, M., Koc, B., Susyal, G., Yilmazer, M. S., Ertekin, F. K., \& Bagdatlioglu, N. (2011). Functional and physicochemical properties of whole egg powder: Effect of spray drying conditions. Journal of Food Science and Technology-mysore, 48(2), 141-149. doi:10. 1007/s13197-010-0159-1

Kumar, S., Gautam, S., Powar, S., \& Sharma, A. (2010). Microbial decontamination of medicinally important herbals using gamma radiation and their biochemical characterisation. Food Chemistry, 119, 328-335. doi:10.1016/j.foodchem.2009.06. 034

Kumaravel, S., Hema, R., Kamaleshwari, A., Yusuf, A. D., Abu, M., Nasir, A. N., ... Peeri, M. (2011). Effect of oven drying on the nutritional properties of whole egg and its components. International Journal of Food and Nutrition Science, 1(1), 4-12.

Min, B., Nam, K. C., Jo, C., \& Ahn, D. U. (2012). Irradiation of shell egg on the physicochemical and functional properties of liquid egg white. Poultry Science, 91(10), 2649-2657. doi:10.3382/ps.2012-02345

Ndife, J., Udobi, C., \& Amaechi, N. (2010). Effect of oven drying on the functional and nutritional properties of whole egg and its components. African Journal of Food Science, 4 .

Nemeth, C., Dalmasi, I., Mraz, B., Friedrich, L., Pastor-Huszar, K., Suhajda, A., ... Balla, C. (2011). Study of long term posttreatment of whole egg powder at $50-55^{\circ} \mathrm{C}$. Polish Journal of Food and Nutrition Sciences, 61. doi:10.2478/v10222-011-0026-4

Rakonjac, S., Bogosavljevic-Boskovic, S., Pavlovski, Z., Skrbic, Z., Doskovic, V., Petrovic, M. D., \& Petricevic, V. (2014). Laying hen rearing systems: A review of major production results and egg quality traits. Worlds Poul- try Science Journal, 70(1), 93-104. doi:10.1017/S0043933914000087

SASMO. (2007). Syrian Arab Standard and Metrology Organization, Microbiological requirements for foods - (second revision). 2179/2007. ICS 67.040.

SASMO. (2010). Syrian Arab Standard and Metrology Organization. Good Irradiation Practices Code to control of the microorganisms and the insect pest in the plant condiment and herbs and spices.3512/2010. ICS 17.240.

Schuck, P., Dolivet, A., Mejean, S., Zhu, P., Blanchard, E., \& Jeantet, R. (2009). Drying by desorption: A tool to determine spray drying parameters. Journal of Food Engineering, 94(2), 199-204. doi:10.1016/j . jfoodeng.2008.08.014

Shahin, A. A. M., Swailam, H. M., \& Abou Zeid, A. A. (2006). Effect of gamma irradiation on hygienic quality and chemical characteristics of dehydrated ostrich eggs. International Journal of Agriculture 83 Biology, 8530, 8-2.

Syamaladevi, R. M., Tang, J., Villa-Rojas, R., Sablani, S., Carter, B., \& Campbell, G. (2016). Influence of water activity on thermal resistance of microorganisms in lowmoisture foods: A review. Comprehensive Reviews in Food Science and Food Safety, 15(2), 353-370. doi:10.1111/1541- 4337. 12190

Tan, T. C., Kanyarat, K., \& Easa, A. (2012). Evaluation of functional properties of egg white obtained from pasteurized shell egg as ingredient in angel food cake. International Food Research Journal, 19, 303-308.

Wong, P. Y., \& Kitts, D. (2002). Physicochemical and functional properties of shell eggs following electron beam irradiation. Journal of the Science of Food and Agriculture, 83, 44-52. doi:10.1002/jsfa.1280 